\title{
Laboratory Model Tests on Stone Column and Pervious Concrete Columns: A Comparative Study
}

\author{
Jignesh Patel ${ }^{1}$, Chandresh Solanki ${ }^{1}$, Yogendra Tandel $^{2, *}$, Bhavin Patel $^{3}$ \\ ${ }^{1}$ Civil Engineering Department, Sardar Vallabhbhai National Institute of Technology, Gujarat, India \\ ${ }^{2}$ Applied Mechanics Department, Government Engineering College Dahod, Gujarat, India \\ ${ }^{3}$ Civil Engineering Department, GIDC Degree Engineering College Navsari, Gujarat, India \\ Received 30 June 2021; received in revised form 02 September 2021; accepted 03 September 2021 \\ DOI: https://doi.org/10.46604/ijeti.2021.7993
}

\begin{abstract}
This study aims to perform laboratory model tests to investigate the load-deformation behavior of stone columns (SCs), pervious concrete columns (PCCs), and composite columns (CCs). Here, CC refers to the column which has the upper portion made of PCC and the lower portion made of SC. The parameters investigated in this study include column diameters, column lengths, and installation methods (pre-cast and cast-in-situ methods). The results of the model tests reveal that the axial load-carrying capacity of PCC is nearly 8 times more than that of SC with the same diameter. Moreover, it is also observed that at the top portion of SC, with the PCC length which is about 3.75 to 5 times the column diameter, the load-carrying capacity can significantly increase. It is concluded that the installation methods have marginal influence on the load-deformation behavior of PCC.
\end{abstract}

Keywords: ground improvement, stone column, pervious concrete column, composite column, model test

\section{Introduction}

Soft soil foundation techniques are very limited owing to the accompanying environmental concerns and high costs. Sand columns or stone columns (SCs) are often employed for the structures that can tolerate some settlements [1]. However, SCs fail due to bulging when subjected to vertical loads. The axial load-carrying capacity of SCs depends on the lateral confining pressure provided by the surrounding soils. In very soft soils, the lateral confining pressure provided by such soils is not adequate, which results in the insufficient load-carrying capacity of the columns [2]. In such soils, pervious concrete columns (PCCs) can be employed because they have higher strength and stiffness independent of the surrounding soil properties and have the permeability comparable to SCs [3].

From the laboratory and full-scale field tests, Kim et al. [4] reported that the SC reinforced by pervious concrete at the upper portion brought the bulging collapse restraining effect and settlement reduction effect. Suleiman et al. [3] evaluated the performance of pervious concrete piles through laboratory model tests in sand, and found that the ultimate load-carrying capacity of pervious concrete pile is about 4.4 times greater than that of the ordinary SC. Based on laboratory model tests, Lin et al. [5] concluded that the load deformation response of a pervious concrete pile can be enhanced by microbial-induced carbonate precipitation. Xu et al. [6] studied the influence of silica ash, cellulose fiber, and mineral powder on the geotechnical properties of pervious concrete piles. The optimum dosage was found about $6 \%$ and $30 \%$ for silica ash and mineral powder, respectively. The lateral load response of a pervious concrete pile was investigated by Ni et al. [7]. Test results confirmed that laterally-loaded pervious concrete ground-improvement piles behave as flexible laterally-loaded piles.

\footnotetext{
* Corresponding author. E-mail address: yogendrakumar.kantilal@gujgov.edu.in

Tel.: +91-02673-263780
} 
They also found that the lateral deflection of the cast-in-place pile was 55\% less than that of the pre-cast pile. The image processing technology, computed tomography (CT), and X-ray techniques are utilized in the microscopic study of porous materials. Stereological and morphological methods are used to extract relevant pore structure features of pervious concretes from planar images [8-9]. Kim et al. [10] investigated the applicability of recycled aggregate for the construction of pervious concrete piles through laboratory model tests. They observed that pervious concrete piles could also accelerate the consolidation of soft clay formation because the concrete piles behave as vertical drains. The laboratory model tests were conducted by Ziccarelli and Valore [11] to find the hydraulic conductivity and strength properties of pervious concrete for deep trench drains to stabilize the slopes. They came to the conclusion that the hydraulic conductivity and strength of pervious concrete should be considered in the mix design, as well as their relationship to the water/cement and aggregate/cement ratios, as well as the aggregate's granulometric composition.

The loading tests of biogrout-improved and unimproved concrete model piles were conducted to evaluate the performance of biogrouts to enhance the toe bearing capacity of pre-cast concrete piles by Xiao et al. [12]. The total bearing capacity of the pre-cast concrete pile with a biogrouted toe was 4.4 times as large as that without biogrouts. Lund et al. [13] investigated the mix design of the pervious concrete fill by the use of an air-entraining admixture, a high-range water reducing admixture, and fibers, and by internal curing using lightweight aggregate to best possibly meet the requirements for a fill material. They observed that the addition of a high-range water reducing admixture and lightweight sand (expanded shale) for internal curing improved the 28-day compressive strength and splitting tensile strength, and the mix design containing lightweight sand showed the improved freeze-thaw durability compared to other mix designs. A series of tests were performed to evaluate the properties of pervious concrete pile composite foundation by Jin et al. [14] in the field. The pervious concrete pile can effectively reduce the acceleration and the excess pore water pressure induced by vibrations, and thus mitigate the liquefaction of ground and reduce the damage of upper structures. According to the laboratory results, Li et al. [15] discovered that the $w / c$ ratio and paste volume have a significant impact on the porosity, permeability, and strength of pervious concrete.

Tandel et al. [16] carried out numerical analyses to investigate the behavior of the composite column (CC) made of pervious concrete at the upper portion and stone aggregate at the lower portion. They concluded that the reinforcing effect of the upper portion of SC increases the load-carrying capacity of SC appreciably. Patel et al. [17] carried out numerical analyses to study the behavior of a grouped CC. They observed that the load-carrying capacity of SC can be enhanced by about 50\% as the length of pervious concrete increases from two to four times the column diameter. Zhang et al. [18] compared the numerical and cast-in-situ test results of the PCC composite foundation under embankment loading. They revealed that PCC can remarkably mitigate the development of the excess pore water pressure and thus enhance the subsoil strength. Zhang et al. [19] did the numerical calculation to study the dynamic performance characteristics of pervious concrete piles composite foundation under earthquake loads, the acceleration response of subgrades, and the development and dissipation of the excess pore water pressure. They have also compared the dynamic performance of pervious concrete piles with that of gravel piles and low-grade concrete piles. It was revealed that the draining-damping coupling effect of pervious concrete piles can improve the deformation compatibility of soils during the earthquake. Rashma et al. [20] compared the shear response of pervious concrete with ordinary SC by numerically simulating a large shear test model, representing the PCC improved ground. It was observed that the PCC improved ground shows better shear performance than the ordinary SC improved ground.

While PCCs have been used in practice, there have not been any systematic investigations to understand the loaddeformation behavior of the CC made of SC and PCC. The present study aims to propose a comprehensive test programme consisting of the model tests on the single PCC, SC, and CC installed in very soft clay. Here, CC refers to the column with the upper portion made of PCC and the lower portion made of SC. The influence of column diameter, PCC length in CC, and column installation effect is investigated in this study. 


\section{Materials and Methods}

\subsection{Test set-up, materials, and test programme}

The model tests are performed on a column installed at the center of the clay prepared in a steel tank (300 mm diameter and $500 \mathrm{~mm}$ height), and the load is applied on the column area. Fig. 1 shows a schematic view of the model column. In all tests, the thickness of the base sand layer and soft clay is kept constant at 150 and $350 \mathrm{~mm}$, respectively. The column diameters used in the model tests are 75 and $100 \mathrm{~mm}$.

The model tests are not performed with any particular prototype in mind, but are shown as a generic study. The model test setup is designed on similar lines as done by Wood et al. [21]. The important details related to boundaries, dimensions, materials, and loading conditions in the model vis-a-vis the actual prototype are given due consideration as presented subsequently. Usually, the $L / d$ ratio in the prototype SCs varies between 3 and 20, in which $L$ and $d$ are the column length and diameter, respectively. The $L / d$ ratios in the model tests for single columns are 3.5 and 4.7.

The model tank boundary for the column load tests is selected based on the unit cell approach. The model tank boundaries are determined on the basis of criteria that the induced stresses should be insignificant at the tank boundaries [22]. Assuming that the footing is located on the top of the columns and the spreading of stress is $2: 1$, so it is at the depth equal to two times the width of the foundation, then the induced stresses may be assumed approximately equal to $11 \%$ of the applied stresses. The sand bed represents the end bearing layer. The thickness of the sand bed is determined based on insignificant stress criteria, assuming that the stress through PCC tip becomes insignificant at the depth equal to 1.5 times the column diameter.

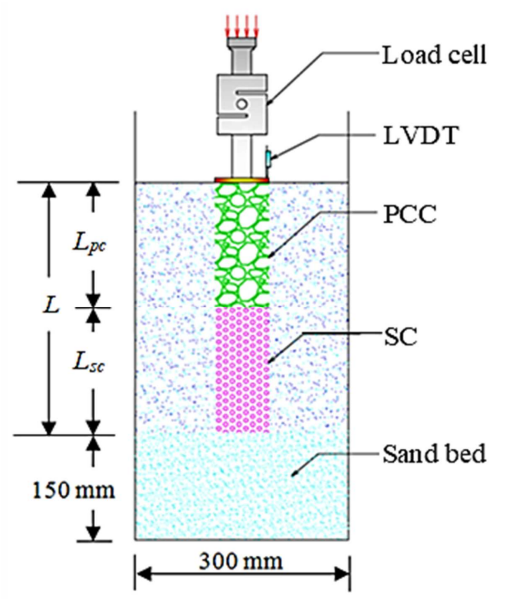

Fig. 1 Schematic of load test arrangement

The soft soil bed is made up of remolded natural clay. The clay used is of the CL classification (as per Unified Soil Classification System (USCS)) and is collected at a depth of $2 \mathrm{~m}$. The sample collected is air-dried and pulverized. The pulverized sample is sieved through a $2 \mathrm{~mm}$ sieve for easy mixing and quicker hydration. Table 1 shows the properties of the soft clay having the void ratio 1.05 and degree of saturation $88 \%$. The undrained cohesion of the soft clay bed is obtained by conducting vane shear tests. Figs. 2-4 show the photographs of the laboratory tests performed on the clay, sand/stone column material and aggregate, and cement, respectively. The typical particle size distribution curve is shown in Fig. 5.

The river sand passing from the $4.75 \mathrm{~mm}$ sieve is used for modeling base sand and SC. The angle of internal friction reported in Table 2 is based on direct shear tests. The sand is compacted to a density of $16 \mathrm{kN} / \mathrm{m}^{3}$. Other properties of the sand are summarized in Table 2. 
Table 1 Properties of clay

\begin{tabular}{|c|c|c|}
\hline Property & Standard & Value \\
\hline Liquid limit (\%) & IS: 2720 (part 5) [23] & 46 \\
\hline Plasticity index (\%) & IS: 2720 (part 5) [23] & 29 \\
\hline Specific gravity & IS: 2720 (part 3/section 1) [24] & 2.64 \\
\hline USCS & ASTM D2487-17e1 [25] & CL \\
\hline Dry unit weight (kN/m ${ }^{3}$ ) & IS: 2720 (part 29) [26] & 12.50 \\
\hline Bulk unit weight $\left(\mathrm{kN} / \mathrm{m}^{3}\right)$ & IS: 2720 (part 29) [26] & 17 \\
\hline Undrained cohesion $(\mathrm{kPa})$ & IS: 2720 (part 30) [27] & 9 \\
\hline Water content (\%) & IS: 2720 (part 2) [28] & 36 \\
\hline Consistency index & IS: 2720 (part 5) [23] & 0.34 \\
\hline
\end{tabular}

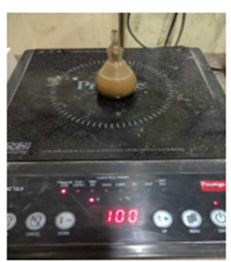

(a) Specific gravity

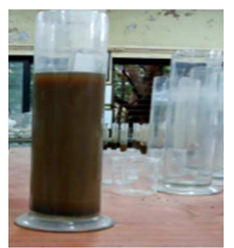

(d) Hydrometer analysis

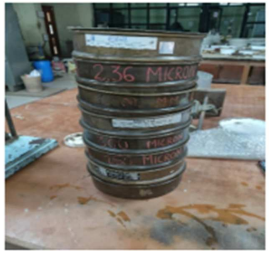

(b) Sieve analysis

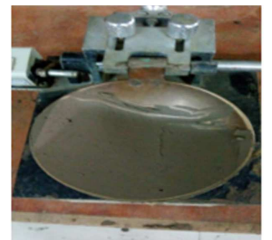

(e) Liquid limit

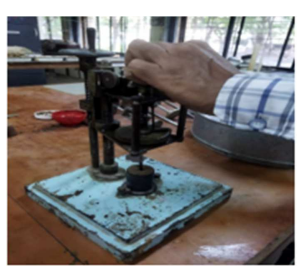

(c) Vane shear

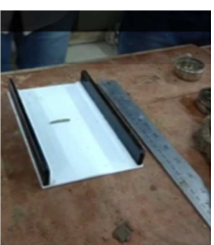

(f) Plastic limit

Fig. 2 Laboratory test on clay

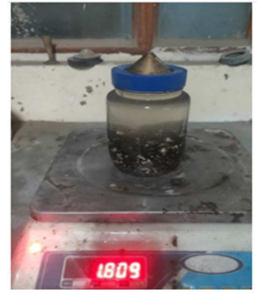

(a) Specific gravity

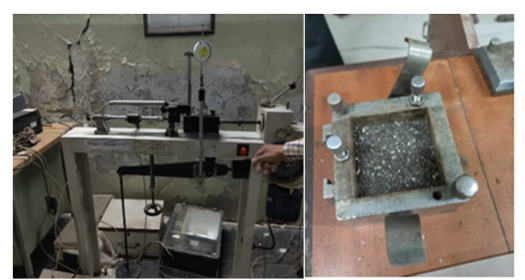

(c) Direct shear box

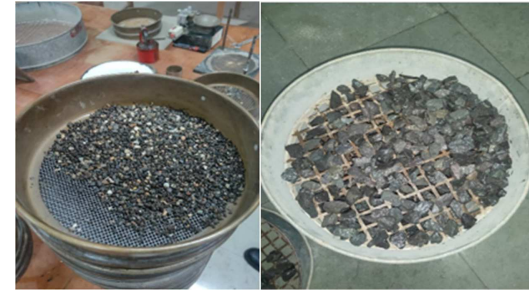

(b) Sieve analysis

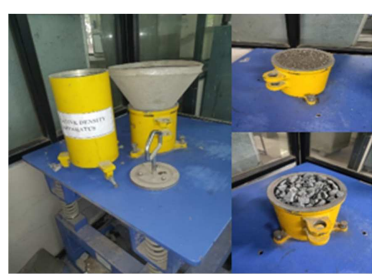

(d) Relative density

Fig. 3 Laboratory test on sand/stone column material and aggregate

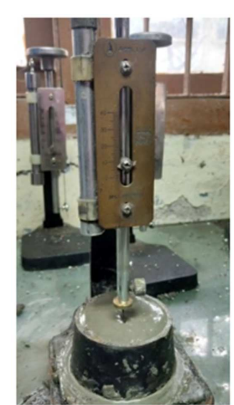

(a) Initial setting time

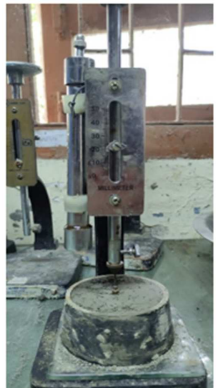

(b) Final setting time

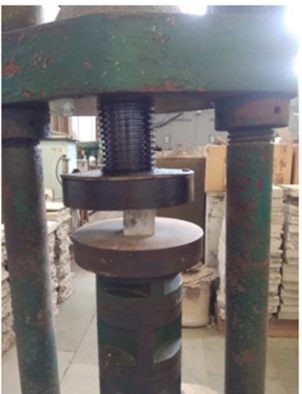

(c) Compressive strength

Fig. 4 Laboratory test on cement 


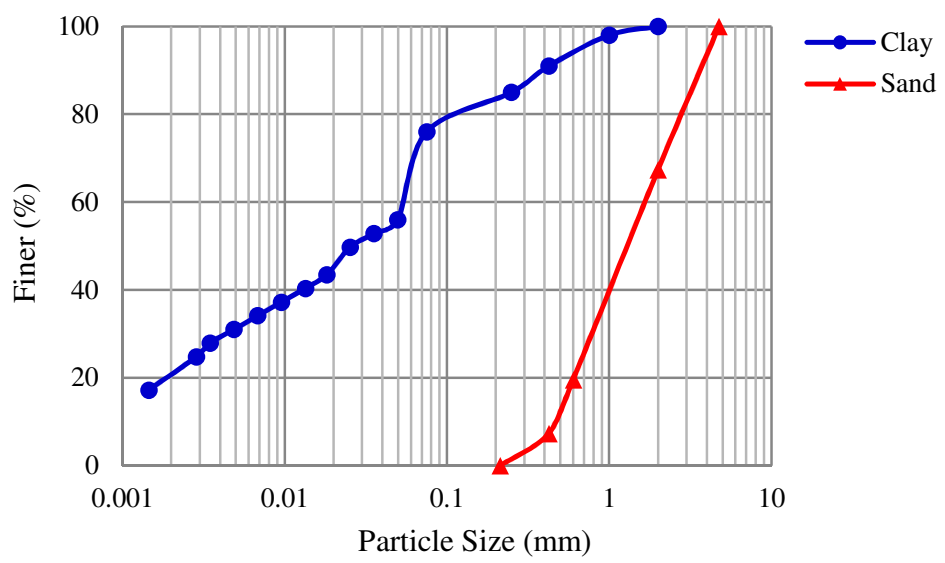

Fig. 5 Particle size distribution of clay and sand

Table 2 Properties of base sand/stone column material

\begin{tabular}{|c|c|c|}
\hline Property & Standard & Value \\
\hline Specific gravity & IS: 2720 (part 3/section 2) [29] & 2.65 \\
\hline Minimum dry unit weight $\left(\mathrm{kN} / \mathrm{m}^{3}\right)$ & IS: 2720 (part 14) [30] & 14.20 \\
\hline Maximum dry unit weight $\left(\mathrm{kN} / \mathrm{m}^{3}\right)$ & IS: 2720 (part 14) [30] & 17.40 \\
\hline Relative density (\%) & IS: 2720 (part 14) [30] & 61 \\
\hline Angle of internal friction $(\mathrm{deg})$ & IS: 2720 (part 13) [31] & 38.4 \\
\hline Coefficient of uniformity & IS: 2720 (part 4) [32] & 3.56 \\
\hline Coefficient of curvature & IS: 2720 (part 4) [32] & 0.72 \\
\hline USCS & ASTM D2487-17e1 [25] & SP \\
\hline
\end{tabular}

Initially, three different grades of aggregate are tested, and the one suitable to pervious concrete is chosen. The typical grain size distribution of the aggregate used for pervious concrete is shown in Fig. 6. The aggregate is washed and sieved, and the portion which passes through the $12.5 \mathrm{~mm}$ sieve and retains by the $9.5 \mathrm{~mm}$ sieve is used for all mixtures. The fraction passing through the $9.5 \mathrm{~mm}$ sieve is removed by sieving. The size of the aggregate is decided based on the dimensions and the permeability of the column required. The properties of aggregate for PCC determined from laboratory tests are reported below in Table 3 .

In the present study, ordinary Portland cement (OPC) of 53 grade is used for pervious concrete. The properties of the OPC used in the study are determined from laboratory tests, as presented in Table 4. Table 5 shows the chemical composition of the cement.

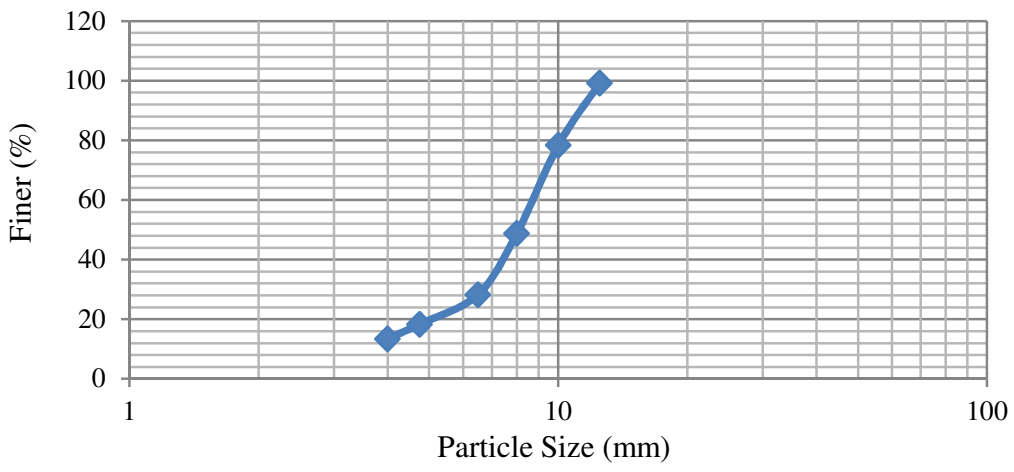

Fig. 6 Particle size distribution of aggregate

Table 3 Properties of aggregate

\begin{tabular}{|c|c|c|}
\hline Property & Standard & Value \\
\hline Size & IS: 2720 (part 4) [32] & $9.5-12.5$ \\
\hline Specific gravity & IS: 2720 (part 3/section 2) [29] & 2.76 \\
\hline Coefficient of uniformity & IS: 2720 (part 4) [32] & 2.25 \\
\hline Coefficient of curvature & IS: 2720 (part 4) [32] & 1.25 \\
\hline
\end{tabular}


Table 4 Properties of cement

\begin{tabular}{|c|c|c|}
\hline Property & Standard & Value \\
\hline Consistency & IS: 4031 (part 4) [33] & $33 \%$ \\
\hline Initial setting time & IS: 4031 (part 5) [34] & $117 \mathrm{~min}$ \\
\hline Final setting time & IS: 4031 (part 5) [34] & $243 \mathrm{~min}$ \\
\hline 3-day compressive strength $\left(\mathrm{N} / \mathrm{mm}^{2}\right)$ & IS: 4031 (part 6) [35] & 25.03 \\
\hline 7-day compressive strength $\left(\mathrm{N} / \mathrm{mm}^{2}\right)$ & IS: 4031 (part 6) [35] & 28.78 \\
\hline 28-day compressive strength $\left(\mathrm{N} / \mathrm{mm}^{2}\right)$ & IS: 4031 (part 6) [35] & 53.35 \\
\hline
\end{tabular}

Table 5 Chemical composition of cement

\begin{tabular}{|c|c|}
\hline Chemical compound & Value (\%) \\
\hline $\mathrm{CaO}$ & 64.12 \\
\hline $\mathrm{SiO}_{2}$ & 20.65 \\
\hline $\mathrm{Al}_{2} \mathrm{O}_{3}$ & 5.32 \\
\hline $\mathrm{Fe}_{2} \mathrm{O}_{3}$ & 4.23 \\
\hline $\mathrm{SO}_{3}$ & 2.16 \\
\hline $\mathrm{MgO}$ & 1.13 \\
\hline $\mathrm{TiO}_{2}$ & - \\
\hline $\mathrm{Na}_{2} \mathrm{O}$ & - \\
\hline Loss of ignition & 2.39 \\
\hline
\end{tabular}

For ground improvement applications, a pervious concrete material needs to be improved with the high stiffness and strength and the permeability comparable to granular piles. A series of pervious concrete mixtures are prepared in order to obtain an adequate compressive strength and permeability. The compressive strength is determined as per ASTM C39 [36]. In addition, the permeability is measured using an in-house designed falling-head apparatus as per ACI-522R [37], as shown in Fig. 7. The permeameter has a polyvinyl chloride (PVC) tube. The tube has an inside diameter of $76 \mathrm{~mm}$ and a height of $914 \mathrm{~mm}$. The sample is installed at the bottom of the tube. Duct Seal (DS-130, Gardner Bender) is used to seal both sides of the sample to prevent water leakages along the sides of the sample. The falling head test is performed for several times to obtain an average value of permeability.

The materials used for pervious concrete mixing include aggregate, cement, water, and plasticizer rheoplast 220. Mixtures are prepared using water/cement ratio 0.33 and aggregate-cement proportion 4.5:1. The main procedure of pervious concrete mixing follows the normal concrete mixing procedure in ASTM C192 [38]. The procedure is used for pervious concrete mixing as summarized in Table 6.

Generally, the aggregate-cement ratios are in the range of 4-6. The typical water/cement ratio ranges between $0.27-0.43$, and the permeability ranges between $0.2-1.1 \mathrm{~cm} / \mathrm{s}$, respectively. The aggregate grading used in pervious concrete are typically either single sized coarse aggregate or grading between 9.5-19 mm [39]. Table 7 shows the composition and properties of pervious concrete mix investigated. In this research work, the aggregate of size 9.50-12.50 is adopted considering the permeability and compressive strength required for PCC. In this work, paste volume is calculated based on the guidelines provided by Chu [40-41].

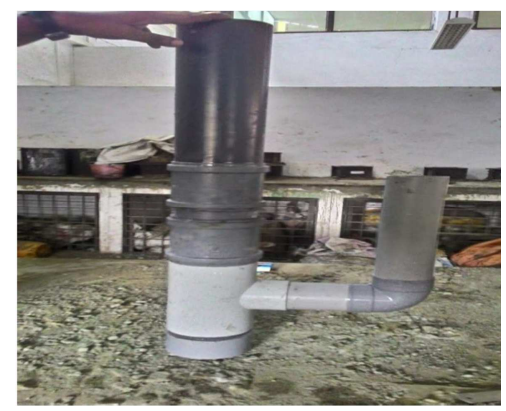

Fig. 7 Falling head permeameter used for permeability testing 
Table 6 Mixing procedure for pervious concrete

\begin{tabular}{|l|c|}
\hline Step 1 & Mix water and Plasticizer rheoplast 220 (1\% by weight of cement) \\
\hline Step 2 & Add the aggregate and $2 / 3$ of water mixture to a mixer \\
\hline Step 3 & Mix together for 1 minute \\
\hline Step 4 & Add the cement and the last $1 / 3$ of water mixture to a mixer \\
\hline Step 5 & Mix thoroughly for 3 minutes \\
\hline Step 6 & Allow to rest for 3 minutes \\
\hline Step 7 & Mix for an additional 2 minutes \\
\hline
\end{tabular}

Table 7 Composition and properties of pervious concrete mix investigated

\begin{tabular}{|c|c|c|c|c|c|c|c|c|c|c|}
\hline \multirow{2}{*}{$\begin{array}{l}\text { Aggregate } \\
\text { size }(\mathrm{mm})\end{array}$} & \multirow{2}{*}{$\begin{array}{l}\text { Water/ } \\
\text { cement } \\
\text { ratio }\end{array}$} & \multirow{2}{*}{$\begin{array}{l}\text { Aggregate } \\
\text {-cement } \\
\text { proportion }\end{array}$} & \multicolumn{4}{|c|}{ Mixture proportions $\left(\mathrm{kg} / \mathrm{m}^{3}\right)$} & \multirow{2}{*}{$\begin{array}{l}\text { Paste } \\
\text { volume } \\
(\%)\end{array}$} & \multicolumn{2}{|c|}{$\begin{array}{c}\text { Compressive } \\
\text { strength }\left(\mathrm{N} / \mathrm{mm}^{2}\right)\end{array}$} & \multirow{2}{*}{$\begin{array}{l}\text { Permeability } \\
(\mathrm{cm} / \mathrm{sec})\end{array}$} \\
\hline & & & Water & Cement & $\begin{array}{l}\text { Aggregate } \\
\text { (coarse) }\end{array}$ & Plasticizer & & 7 days & 28 days & \\
\hline $12.50-16.0$ & 0.33 & $4.5: 1$ & 113 & 343 & 1543 & 3.43 & 29.00 & 3.89 & 5.13 & 0.760 \\
\hline $9.50-12.50$ & 0.33 & $4.5: 1$ & 113 & 343 & 1543 & 3.43 & 29.00 & 4.54 & 6.03 & 0.548 \\
\hline $4.75-9.50$ & 0.33 & $4.5: 1$ & 113 & 343 & 1543 & 3.43 & 29.58 & 9.77 & 12.89 & 0.283 \\
\hline
\end{tabular}

In the present work, 13 model load tests in total are performed. Load tests are conducted on the clay bed, SC, PCC, and $\mathrm{CC}$ to compare their relative performance. Four series of tests are conducted. The first series of tests are performed on the clay bed without any columns. The second series of tests are performed on SCs with the diameters 75 and $100 \mathrm{~mm}$. The third series of tests are performed on PCCs with the diameters 75 and $100 \mathrm{~mm}$. For the fourth series of tests, model tests are carried out on 75 and $100 \mathrm{~mm}$ diameter CCs with the PCC length equal to $0.25 \mathrm{~L}, 0.50 \mathrm{~L}$, and $0.75 \mathrm{~L}$, where $L$ is the total length of the column. Two additional tests are performed considering pre-cast construction method for PCC on 75 and 100 mm diameter PCC. Table 8 shows the experimental program for model test on single column.

Table 8 Experimental program for model test on single column

\begin{tabular}{|c|c|c|c|c|c|}
\hline Model no. & $D(\mathrm{~mm})$ & $L(\mathrm{~mm})$ & $L_{p c}(\mathrm{~mm})$ & $L_{s c}(\mathrm{~mm})$ & Type \\
\hline 1 & - & - & - & - & Clay \\
\hline 2 & 75 & 350 & - & 350 & SC \\
\hline 3 & 100 & 350 & - & 350 & SC \\
\hline 4 & 75 & 350 & 350 & - & PCC-cast-in-situ \\
\hline 5 & 100 & 350 & 350 & - & PCC-cast-in-situ \\
\hline 6 & 75 & 350 & 87.50 & 262.50 & CC-cast-in-situ \\
\hline 7 & 75 & 350 & 175 & 175 & CC-cast-in-situ \\
\hline 8 & 75 & 350 & 262.50 & 87.50 & CC-cast-in-situ \\
\hline 9 & 100 & 350 & 87.50 & 262.50 & CC-cast-in-situ \\
\hline 10 & 100 & 350 & 175 & 175 & CC-cast-in-situ \\
\hline 11 & 100 & 350 & 262.50 & 87.50 & CC-cast-in-situ \\
\hline 12 & 75 & 350 & 350 & - & PCC-pre-cast \\
\hline 13 & 100 & 350 & 350 & - & PCC-pre-cast \\
\hline
\end{tabular}

\subsection{Sand bed, clay bed, and column construction}

The bottom $(150 \mathrm{~mm})$ of the model steel tank is filled with dense sand, which has a relative density of $61 \%$. The sand is poured through a hopper from a defined height to achieve the required relative density based on sand rain method as suggested by Suleiman et al. [3]. This system consists of a bottom dump soil container with an attached sieve that rains the soil into the model tank. The height for pouring the sand through the hopper is determined by trial-and-error method. In this case, the height of fall is found to be $350 \mathrm{~mm}$.

The clay bed is prepared in accordance with the procedure adopted by Ambily and Gandhi [42] and Vekli et al. [43]. In the present study, the clay bed thickness is kept equal to $350 \mathrm{~mm}$. The clay bed is prepared with a shear strength of $9 \mathrm{kPa}$ by a molding procedure. The required quantity of water (36\%) determined by trial and error is added to the clay. The bulk unit 
weight at $36 \%$ water content is found as $17 \mathrm{kN} / \mathrm{m}^{3}$. Initially, the soil is thoroughly mixed with the water and kept covered with a wet jute fabric for 48 hours in order to achieve uniform consistency. After 48 hours of hydration, the soil is mixed and kneaded well, and checked for moisture content. The loss of water, if any due to evaporation, is compensated by adding the water before forming the bed. A thin coat of grease is applied along the inner surface of tank wall to reduce the friction between the clay and the tank wall. The paste is placed in the tank in $50 \mathrm{~mm}$ layers by molding by hand under the control of a constant unit weight. For each layer, equal amounts of clay are used. In addition, the samples are taken from each layer after the layers are established. The tests begin once the unit weight of the samples is determined close enough. Care is taken to ensure that no significant air voids are left out in the test bed.

The installation of the columns is carried out as per the method suggested by Ali et al. [44]. For the installation of the full-length SC, first of all, the casing pipe of PVC with an outer dimeter equal to the column diameter is kept at the center of the tank above the sand bed. The clay bed is prepared around the casing pipe to a thickness of $50 \mathrm{~mm}$, followed by the charging of stone materials in the casing pipe, compaction, and lifting of the casing pipe to ensure a $50 \mathrm{~mm}$ thickness of SC. For the construction of SC, the quantity of the sand required to form the column is pre-measured and charged into the casing pipe in the layer with $50 \mathrm{~mm}$ thickness. The pipe is then raised in stages ensuring a minimum of $10 \mathrm{~mm}$ penetration below the top level of the placed sand. To achieve a uniform density for the column, compaction is given with a $1.3 \mathrm{~kg}$ circular steel rod with 12 blows of $150 \mathrm{~mm}$ drop to each layer. This light compaction effort is adopted to ensure that there is no significant lateral bulging of the column. The corresponding density is found to be $16 \mathrm{kN} / \mathrm{m}^{3}$ for SC. The procedure is repeated until the column is completed to the full height.

In the case of the full-length PCC installation, pre-cast column method is applied. For the pre-cast PCC, first of all, pervious concrete is poured into the PVC casing pipe which is split into two halves. The PCC is removed from the PVC casing pipe after 24 hours and kept in water for 7 days to cure. The corresponding density is found to be $15 \mathrm{kN} / \mathrm{m}^{3}$ for PCC. The PCC is installed at the tank's center, and the clay bed surrounding the column is prepared as per the SC preparation method. For the installation of the full-length cast-in-situ PCC, a PVC pipe having its outer diameter equal to the required diameter of the column is first placed at the properly marked center of the tank on the sand bed. Around this pipe, the clay bed is formed as described earlier as in the case of the installation of SC. The CC essentially consists of PCC at the upper portion and SC at the lower portion. For the construction of CC, the lower portion of column consisted of SC is constructed as per the procedure followed in the construction of the full-length SC. After the construction of SC, the pre-cast concrete column is placed above the SC portion, and the clay bed is prepared above the PCC portion.

\subsection{Testing methodology}

After the construction of the columns, the axial load is applied at a constant rate of $1.2 \mathrm{~mm} / \mathrm{min}$ through a square steel plate of the dimension equal to the column diameter. For a single column, the loading plate is kept equal to the diameter of SC. The loading plate is displaced by a mechanical gear arrangement fixed on a reaction loading frame. The loads corresponding to different displacements are measured using a load cell (having an accuracy of $0.01 \mathrm{kN}$ ). The deformation is measured using a linear variable displacement transducer (LVDT), which has an accuracy of $0.01 \mathrm{~mm}$. Since the loading is rapid, it is essentially undrained loading, which simulates loading immediately after construction. The tests are continued up to vertical settlements of $50 \mathrm{~mm}$. One of the load test arrangements is shown in Fig. 8.

After the completion of each test, the deformed shape of SC is established by carefully removing the sand and filling the cavity with a paste of plaster of Paris. When this material is mixed with water, it reforms into a thick paste, which cannot penetrate in clay due to high viscosity. After hardening, within a day, it acquires the shape of the deformed SC. The PCC is exhumed to visualize the deformed shape (Fig. 9). 


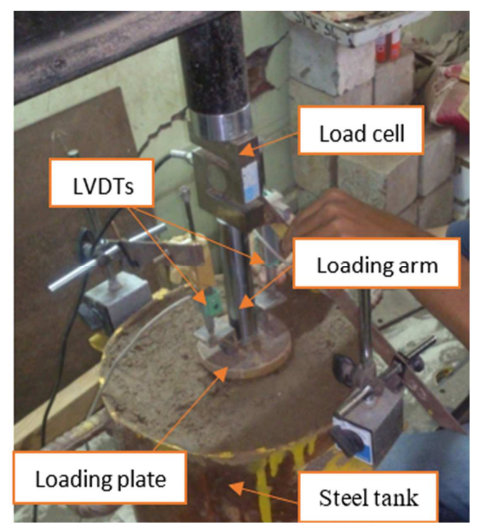

Fig. 8 Model load test arrangement

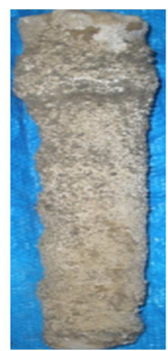

(a) The plaster of Paris molded

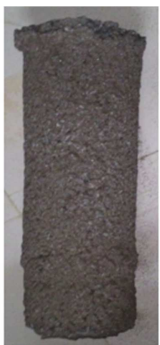
in the exhumed SC

(b) PCC

Fig. 9 The exhumed column after load test

\section{Results and Discussion}

\subsection{Effect of pervious concrete}

To compare the behavior of SC with PCC, the load tests are also performed on the end bearing SC and PCC. Fig. 10 shows the load-settlement results obtained from the experiments for both SC and PCC of $75 \mathrm{~mm}$ diameter. From this figure, it can be said that for very small settlements, the mobilized load on the top of PCC is more than that of SC. This is consistent with the findings of Suleiman et al. [3], Kim et al. [4], and Munaga et al. [45], all of which were based on laboratory model tests on PCCs. There is a clear failure observed for SC whereas PCC does not fail at large strain. This may be due to the bulges of SC because of the inadequate lateral confinement pressure provided by the surrounding soils. With the low confining pressure provided by the surrounding soils, the SC fails due to bulging into the surrounding soils (Fig. 9(a)). The bulged zone is approximately 2D below the surface of the soil surface. The PCC fails due to punching vertically into the soils (Fig. 9(b)). Similar failure patterns are observed by Ni [46].

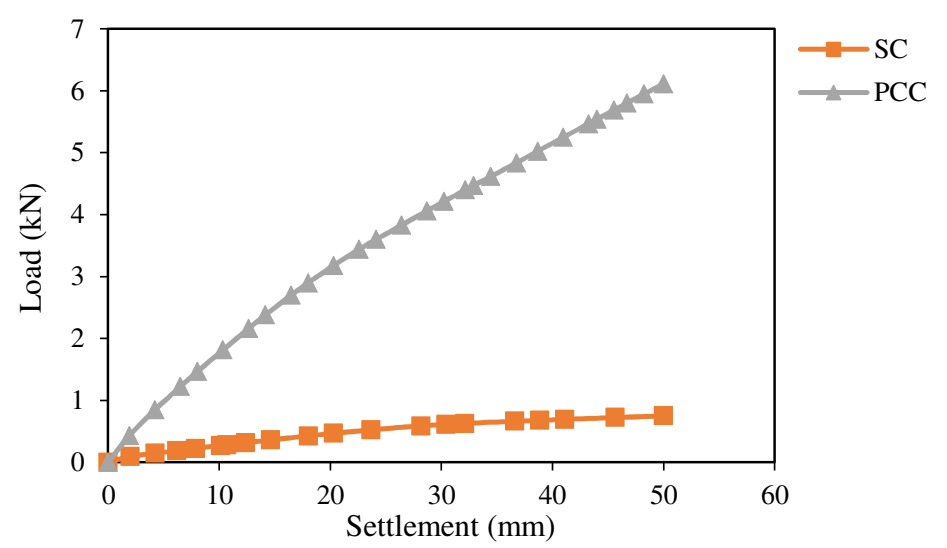

Fig. 10 Load-settlement behavior of the $75 \mathrm{~mm}$ diameter SC and PCC 
Unlike SC, PCC does not experience bulging into the surrounding soils, so it can be used in the soft soils. The vertical settlements in SC appear to be mostly due to lateral deformation of the column material rather than vertical settlements because of the compression of column material under load. However, in PCC, the vertical settlements are distributed along the column length having end bearing soil contribution in load-carrying capacity. The load-carrying capacity of PCC at 50 mm settlement is about 8 times more than that of SC.

\subsection{Analytical predictions}

The maximum stress on various SCs is compared to the limiting axial stress $\left(\sigma_{v}\right)$ on SCs, which is given by Hughes et al. [47] and IS: 15284 (part 1) [48].

$$
\sigma_{v}=\left(\sigma_{r 0}+4 C_{u}\right) K p_{c o l}
$$

In the preceding equation, $\sigma_{r 0}$ is the initial effective radial stress computed at an average depth of twice the column diameter. $K p_{c o l}=\tan ^{2}(45+\varphi / 2)$, where $\varphi$ is the angle of internal friction of the SC material. The limiting axial stress on the column is calculated using a $K_{0}$ of 1.0 for the soft soils and the properties of the soft clay and SC material described earlier in the study.

The total limiting load on SC is calculated and compared to the maximum load (corresponding to $50 \mathrm{~mm}$ settlement) obtained from the experiments for different SC diameters. The comparison of the experimental and analytical values matches very well, as shown in Fig. 11. This consistent comparison for all diameters indicates that the clay bed and SCs in the tests are prepared uniformly. Some of the tests are repeated in order to ensure that the data is consistent. The comparison is found to be excellent, with less than $5 \%$ variation in the results between tests.

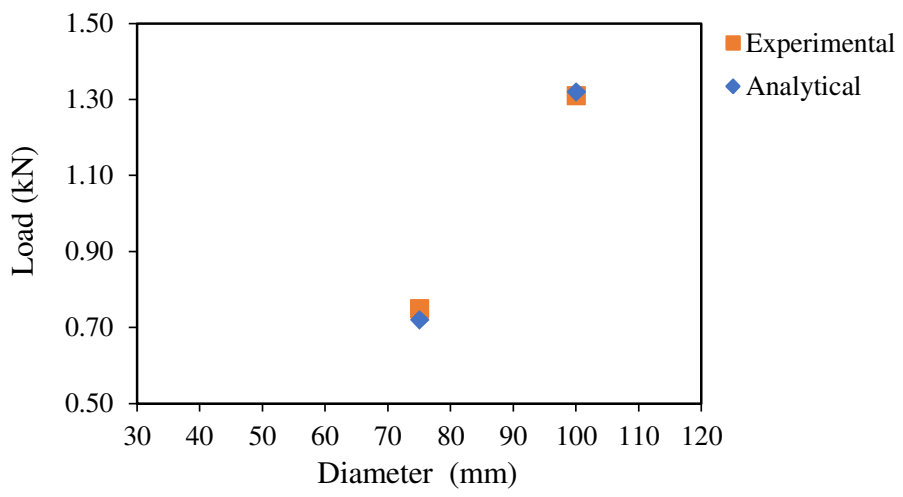

Fig. 11 Comparison of analytical and experimental results

\subsection{Effect of column diameter}

In this present study, the influence of column diameters is studied by varying the diameter from 75 to $100 \mathrm{~mm}$. Fig. 12 shows the load-settlement response of 75 and $100 \mathrm{~mm}$ diameter SC and PCC. One can say that the load-settlement behavior of SC with different diameters is more or less the same. There is no significant changes on load-settlement response. On the other hand, the load-carrying capacity of PCC increases with the increase in the column diameter. For instance, the loadcarrying capacity of $100 \mathrm{~mm}$ diameter PCC is about $65 \%$ more than that of $75 \mathrm{~mm}$ diameter PCC. The increase in the loadcarrying capacity of PCC is due to the increase in skin friction with the increase in diameter.

Fig. 13 shows the mobilized loads at $50 \mathrm{~mm}$ vertical settlement for SC and PCC at varying diameters. From this figure, it can be seen that the mobilized load for PCC increases remarkably with the increase in the column diameter. For instance, by changing the diameter of PCC from 75 to $100 \mathrm{~mm}$, the mobilized load increases by $65 \%$. 


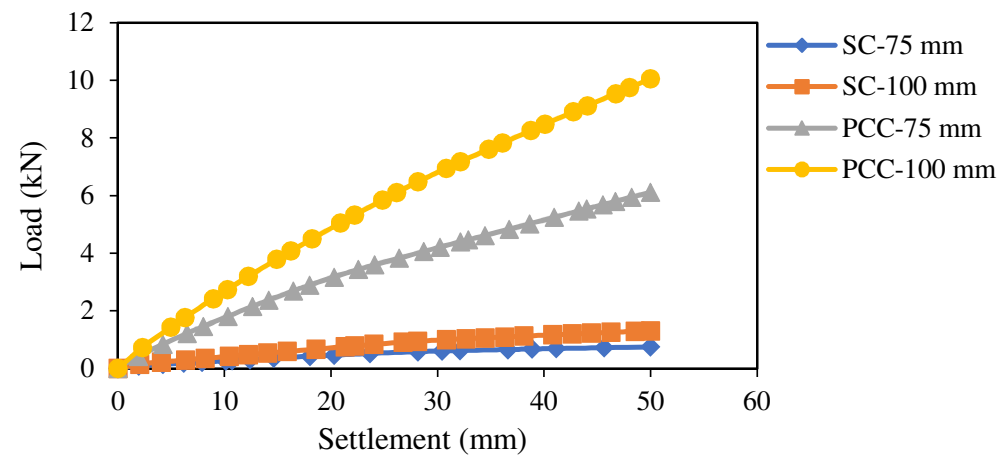

Fig. 12 Influence of column diameter on the load-settlement behavior of SC and PCC

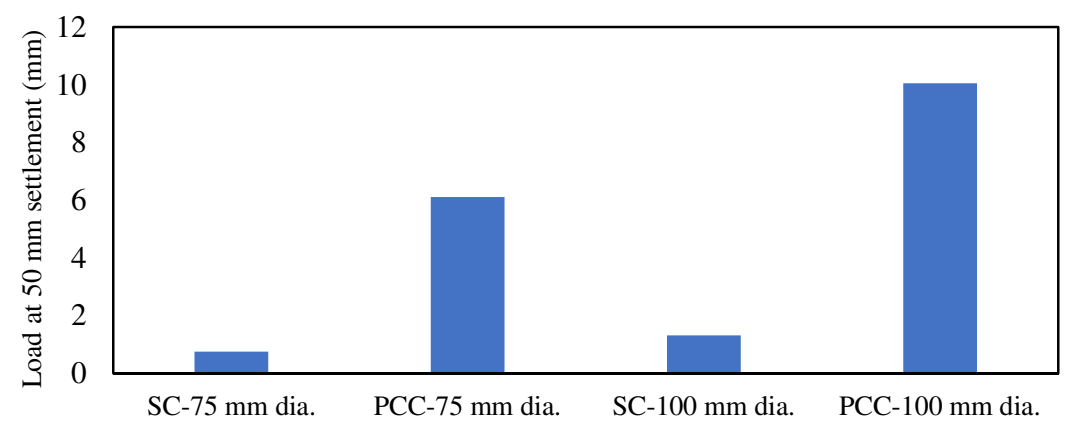

Fig. 13 Load variation corresponding to $50 \mathrm{~mm}$ settlement with column diameter

\subsection{Effect of column length}

Hughes and Withers [49] and Madhav and Miura [50] stated that lateral deformation is the most common failure mode that occurs in the top portion of SCs. Therefore, it may be sufficient to partly strengthen only the top portion of SC. It may not be necessary to install PCC up to full depth of soft clay. Thus, it is decided to provide pervious concrete near the top portion of the column ranging from 0.25 to 0.75 times the column length. Figs. 14 and 15 show the load-settlement response of the full-length SC and PCC along with CC for 75 and $100 \mathrm{~mm}$ column diameter, respectively. It is seen that with the increase in the length of PCC for CC, the load-carrying capacity of CC increases by 2.81 and 3.01 times than that of SC, respectively, for 75 and $100 \mathrm{~mm}$ column diameter. This length is $5 d$ and $3.75 d$ for 75 and 100 mm column diameter, respectively, where $d$ is the diameter of the column.

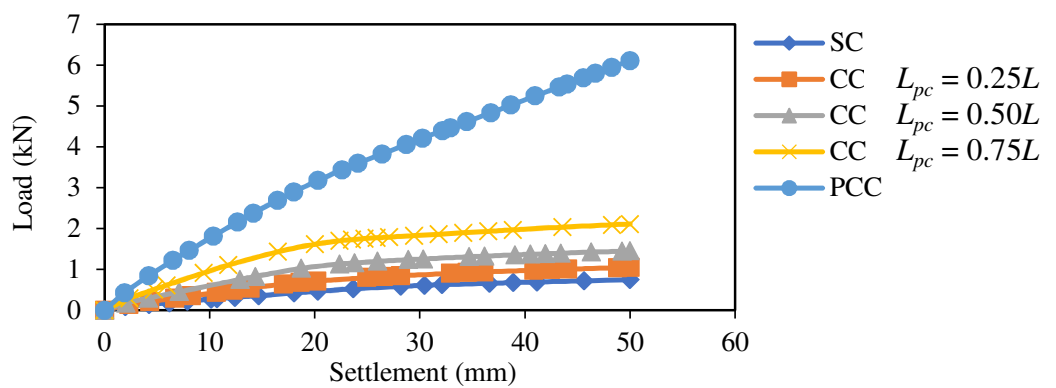

Fig. 14 Load-settlement behavior of the $75 \mathrm{~mm}$ diameter SC and CC

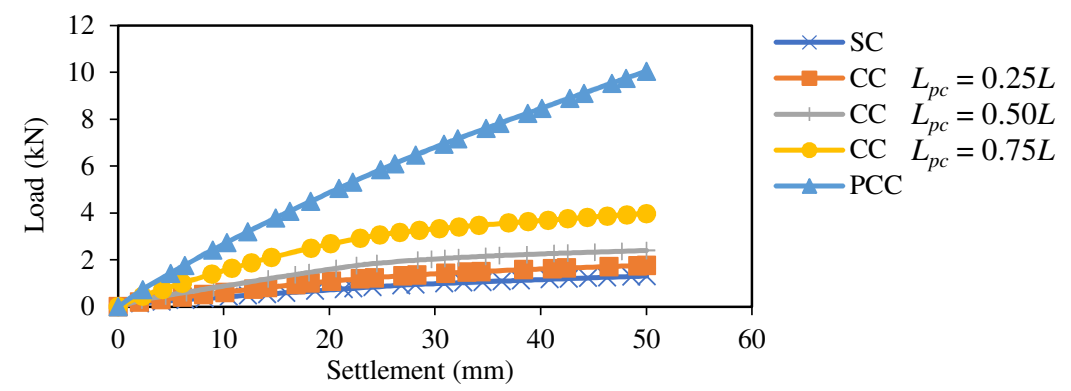

Fig. 15 Load-settlement behavior of the $100 \mathrm{~mm}$ diameter SC and CC 
To better understand the behavior of columns with varying PCC length, mobilized vertical loads at $50 \mathrm{~mm}$ vertical settlement are plotted in Fig. 16. From this figure, it can be seen that pervious concrete up to a depth of four times the column diameter can significantly improve the performance of SC. For instance, at $50 \mathrm{~mm}$ settlement, the mobilized vertical load on a column with a length of pervious concrete of $4 d$ (i.e., $L_{p c}=0.85 L$ ) is 5 times greater than that of a SC for $75 \mathrm{~mm}$ column diameter.

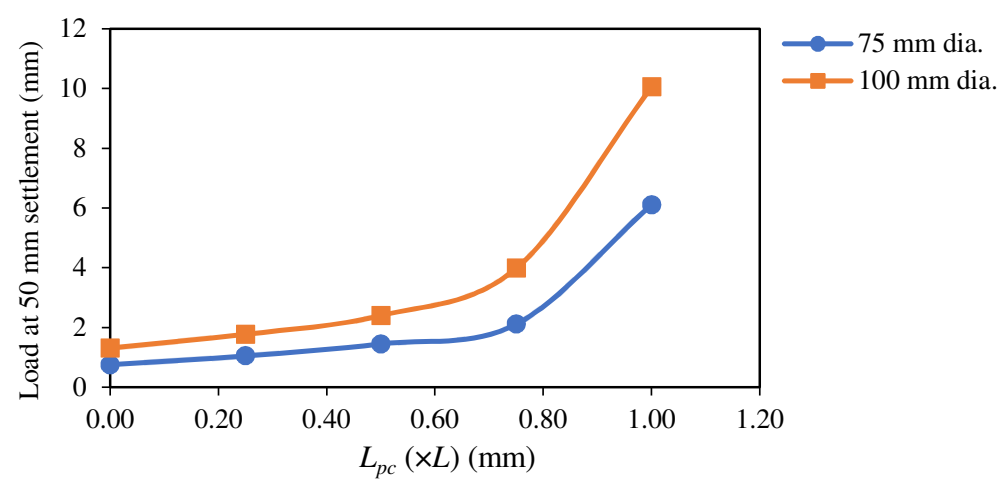

Fig. 16 Mobilized vertical load on a column as a function of $L_{p c}$

\subsection{Effect of installation}

Figs. 17 and 18 present the load-settlement response of the pre-cast and the cast-in-situ 75 and 100 mm diameter PCCs, respectively. These figures indicate the load-carrying capacity enhancing effect with the cast-in-situ PCC. This finding is comparable to that of Suleiman et al. [3], who based their findings on experiments. These tests are conducted to compare the load-settlement response of two similar pervious concrete piles that are installed using different methods. The load at $50 \mathrm{~mm}$ settlement of $75 \mathrm{~mm}$ diameter column with the cast-in-situ installation method is $18 \%$ more than that with the pre-cast method. Also, the load at $50 \mathrm{~mm}$ settlement of $100 \mathrm{~mm}$ diameter column with the cast-in-situ installation method is $19 \%$ more than that with the pre-cast method. The difference between the loads of the two PCCs occurs because the installation methods have marginal effects on the surrounding soil properties. The installation with cast-in-situ method results in an increase of the frictional stress transferred at the soil-pile interface.

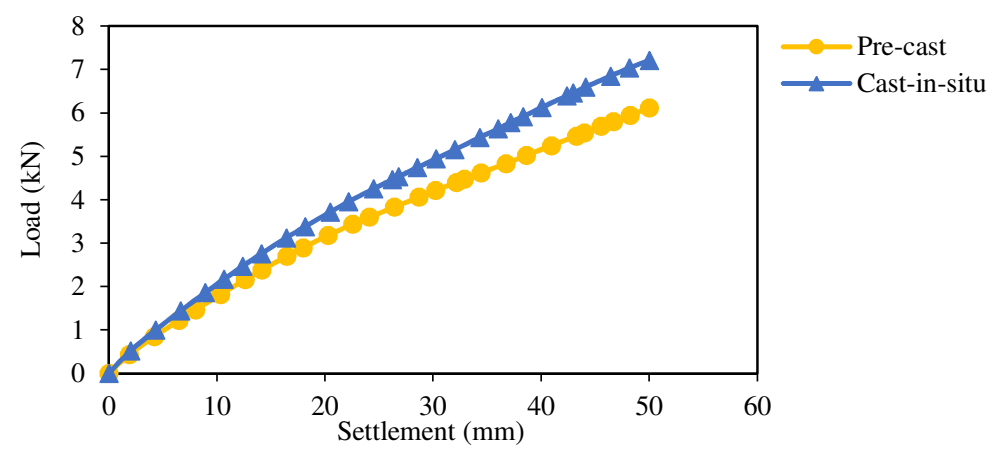

Fig. 17 Load-settlement behavior of the $75 \mathrm{~mm}$ diameter PCC with installation effect

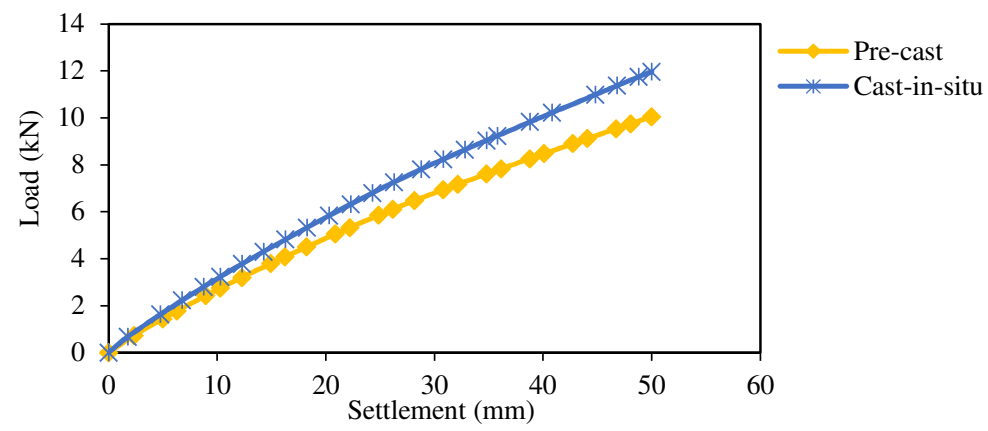

Fig. 18 Load-settlement behavior of the $100 \mathrm{~mm}$ diameter PCC with installation effect 


\section{Conclusions}

In this study, the results of laboratory model tests on SCs, PCCs, and CCs are presented. The trends revealed by these laboratory tests are consistent with the findings reported in the literature. The following conclusions are drawn from the present study.

(1) The full-length PCC, which has the same dimension and installation method as SC, has the load that is 8 times greater than that of $\mathrm{SC}$ at $50 \mathrm{~mm}$ settlement.

(2) The full-length PCC fails due to vertically punching into the soils at the column tip, while the SC fails due to bulging outward into the surrounding soils. The CC fails due to bulging of SC at the junction of PCC and SC portion.

(3) The installation methods have marginal effects on the response of PCC. When comparing the response of the two PCCs installed using different methods (the pre-cast column and the cast-in-situ column), the load of the cast-in-situ column is 19\% greater than that of the pre-cast column. The cast-in-situ installation of PCC results in an increase of the maximum frictional stress transferred at the soil-column interface.

(4) The increase in SC diameter does not have appreciable influence on the load-carrying capacity. For PCC, the diameter has significant effects on the load-carrying capacity because of the mobilization of the higher end bearing resistance provided by end bearing soils.

(5) The performance of CC is very close to that of the full-length PCC. This shows that the reinforcement of SC by pervious concrete is needed only where the bulges take place.

\section{Acknowledgements}

The authors wish to express their gratitude to Gujarat Council on Science and Technology (GUJCOST), Department of Science and Technology, Gujarat, grant no. GUJCOST/MRP/2015-16/2612 dated 28/03/2016 for funding this project.

\section{Conflicts of Interest}

The authors claim no conflict of interest.

\section{References}

[1] J. T. Shahu, M. R. Madhav, and S. Hayashi, "Analysis of Soft Ground-Granular Pile-Granular Mat System," Computers and Geotechnics, vol. 27, no. 1, pp. 45-62, July 2000.

[2] D. Alexiew, C. Moormann, and H. Jud, "Foundation of a Coal/Coke Stockyard on Soft Soil with Geotextile Encased Columns and Horizontal Reinforcement," 17th International Conference on Soil Mechanics and Geotechnical Engineering, pp. 2236-2239, October 2009.

[3] M. T. Suleiman, L. Ni, and A. Raich, "Development of Pervious Concrete Pile Ground-Improvement Alternative and Behavior Under Vertical Loading," Journal of Geotechnical and Geoenvironmental Engineering, vol. 140, no. 7, 04014035, July 2014.

[4] H. T. Kim, C. H. Yoo, J. S. Hwang, and Y. J. Sim, "Application of Porous Concrete to a Structural Foundation in Soft Ground," Advanced Materials Research, vols. 26-28, pp. 895-898, October 2007.

[5] H. Lin, M. T. Suleiman, H. M. Jabbour, D. G. Brown, and E. Kavazanjian, "Enhancing the Axial Compression Response of Pervious Concrete Ground Improvement Piles Using Biogrouting," Journal of Geotechnical and Geoenvironmental Engineering, vol. 142, no. 10, 04016045, October 2016.

[6] T. Xu, P. Huang, L. Lei, C. Luo, and Z. Feng, "Additive Material Effects on Geotechnical Performance of Pervious Concrete," Electronic Journal of Geotechnical Engineering, vol. 19, pp. 6625-6633, 2014. 
[7] L. Ni, M. T. Suleiman, and A. Raich, "Behavior Soil-Structure Interaction of Pervious Concrete Ground-Improvement Piles Under Lateral Loading," Journal of Geotechnical and Geoenvironmental Engineering, vol. 142, no. 2, 04015071, February 2016.

[8] B. Rehder, K. Banh, and N. Neithalath, "Fracture Behavior of Pervious Concretes: The Effects of Pore Structure and Fibers," Engineering Fracture Mechanics, vol. 118, pp. 1-16, March 2014.

[9] M. S. Sumanasooriya and N. Neithalath, "Stereology- and Morphology-Based Pore Structure Descriptors of Enhanced Porosity (Pervious) Concretes,” ACI Materials Journal, vol. 106, no. 5, pp. 429-438, September 2009.

[10] S. Kim, D. Lee, J. Lee, S. K. You, and H. Choi, “Application of Recycled Aggregate Porous Concrete Pile (RAPP) to Improve Soft Ground,” Journal of Material Cycles and Waste Management, vol. 14, no. 4, pp. 360-370, August 2012.

[11] M. Ziccarelli and C. Valore, "Hydraulic Conductivity and Strength of Pervious Concrete for Deep Trench Drains," Geomechanics for Energy and the Environment, vol. 18, pp. 41-55, June 2019.

[12] Y. Xiao, A. W. Stuedlein, Z. Pan, H. Liu, T. M. Evans, X. He, et al., "Toe-Bearing Capacity of Precast Concrete Piles through Biogrouting Improvement,” Journal of Geotechnical and Geoenvironmental Engineering, vol. 146, no. 12, 06020026, December 2020.

[13] M. S. Lund, J. T. Kevern, V. R. Schaefer, and K. K. Hansen, "Mix Design for Improved Strength and Freeze-Thaw Durability of Pervious Concrete Fill in Pearl-Chain Bridges," Materials and Structures, vol. 50, no. 1, 42, February 2017.

[14] Q. Jin, X. Cui, S. Cui, J. Zhang, F. Lian, X. Wang, et al., "In Situ Evaluation and Analysis of Improvement Effects of Pervious Concrete Pile on Alluvial Silt Ground," Geomechanics and Geoengineering, vol. 16, no. 3, pp. $211-222$, 2021.

[15] L. G. Li, J. J. Feng, J. Zhu, S. H. Chu, and A. K. H. Kwan, "Pervious Concrete: Effects of Porosity on Permeability and Strength," Magazine of Concrete Research, vol. 73, no. 2, pp. 69-79, January 2021.

[16] Y. K. Tandel, C. H. Solanki, and A. K. Desai, "Application of Pervious Concrete for Strengthening of Stone Column for Ground Improvement," 8th Biennial Conference on Structural Engineering Convention, pp. 177-181, December 2012.

[17] J. Patel, Y. Tandel, J. Joseph, and C. Solanki, "Numerical Study of Behavior of a Group Pile Made of Pervious Concrete and Stone Aggregate," 8th International Conference on Electrical, Electronics, and Civil Engineering, pp. 45-48, January 2016.

[18] J. Zhang, X. Cui, D. Huang, Q. Jin, J. Lou, and W. Tang, "Numerical Simulation of Consolidation Settlement of Pervious Concrete Pile Composite Foundation under Road Embankment," International Journal of Geomechanics, vol. 16, no. 1, B4015006, September 2015.

[19] J. Zhang, X. Cui, R. Lan, Y. Zhao, H. Lv, Q. Xue, et al., "Dynamic Performance Characteristics of Pervious Concrete Pile Composite Foundations under Earthquake Loads,” Journal of Performance of Constructed Facilities, vol. 31, no. 5, 04017064 , October 2017.

[20] R. S. V. Rashma, R. Shivashankar, and B. R. Jayalekshmi, "Shear Response of Pervious Concrete Column Improved Ground," Indian Geotechnical Journal, in press.

[21] D. M. Wood, W. Hu, and D. F. Nash, "Group Effects in Stone Column Foundations: Model Tests," Geotechnique, vol. 56, no. 6, pp. 689-698, December 2000.

[22] J. T. Shahu and Y. R. Reddy, "Clayey Soil Reinforced with Stone Column Group: Model Tests and Analyses,” Journal of Geotechnical and Geoenvironmental Engineering, vol. 137, no. 12, pp. 1265-1274, December 2011.

[23] Methods of Test for Soils: Part 5 Determination of Liquid and Plastic Limit, IS: 2720 (Part 5), 1985.

[24] Methods of Test for Soils: Part 3 Determination of Specific Gravity, Section 1 Fine Grained Soils, IS: 2720 (Part 3/Section 1), 1980.

[25] Standard Practice for Classification of Soils for Engineering Purposes (Unified Soil Classification System), ASTM D2487-17e1, 2017.

[26] Methods of Test for Soils: Part 29 Determination of Dry Density of Soils In-Place by the Core-Cutter Method, IS: 2720 (Part 29), 1975.

[27] Methods of Test for Soils: Part 30 Laboratory Vane Shear Test,” IS: 2720 (Part 30), 1980.

[28] Methods of Test for Soils: Part 2 Determination of Water Content," IS: 2720 (Part 2), 1973.

[29] Methods of Test for Soils: Part 3 Determination of Specific Gravity, Section 2 Fine, Medium and Coarse Grained Soils, IS: 2720 (Part 3/Section 2), 1980.

[30] Methods of Test for Soils: Part 14 Determination of Density Index (Relative Density) of Cohesionless Soils, IS: 2720 (Part 14), 1983.

[31] Methods of Test for Soils: Part 13 Direct Shear Test, IS: 2720 (Part 13), 1986.

[32] Methods of Test for Soils: Part 4 Grain Size Analysis, IS: 2720 (Part 4), 1985. 
[33] Methods of Physical Tests for Hydraulic Cement: Part 4 Determination of Consistency of Standard Cement Paste, IS: 4031 (Part 4), 1988.

[34] Methods of Physical Tests for Hydraulic Cement: Part 5 Determination of Initial and Final Setting Times, IS: 4031 (Part 5), 1988.

[35] Methods of Physical Tests for Hydraulic Cement: Part 6 Determination of Compressive Strength of Hydraulic Cement Other Than Masonry Cement, IS: 4031 (Part 6), 1988.

[36] Standard Test Method for Compressive Strength of Cylindrical Concrete Specimens, ASTM C39, 2021.

[37] ACI Committee 522, Pervious Concrete, Farmington Hills: American Concrete Institute, 2010.

[38] Standard Practice for Making and Curing Concrete Test Specimens in the Laboratory, ASTM C192, 2019.

[39] M. Sonebi, M. Bassuoni, and A. Yahia, "Pervious Concrete: Mix Design, Properties and Applications," RILEM Technical Letters, vol. 1, pp. 109-115, March 2016.

[40] S. H. Chu, "Effect of Paste Volume on Fresh and Hardened Properties of Concrete," Construction and Building Materials, vol. 218, pp. 284-294, September 2019.

[41] S. H. Chu, "Development of Infilled Cementitious Composites (ICC)," Composite Structures, vol. 267, 113885, July 2021.

[42] A. P. Ambily and S. R. Gandhi, "Behavior of Stone Columns Based on Experimental and FEM Analysis," Journal of Geotechnical and Geoenvironmental Engineering, vol. 133, no. 4, pp. 405-415, April 2007.

[43] M. Vekli, M. Aytekin, S. B. İkizler, and Ü. Çalik, "Experimental and Numerical Investigation of Slope Stabilization by Stone Columns," Natural Hazards, vol. 64, no. 1, pp. 797-820, October 2012.

[44] K. Ali, J. T. Shahu, and K. G. Sharma, "Model Tests on Geosynthetic-Reinforced Stone Columns: A Comparative Study," Geosynthetics International, vol. 19, no. 4, pp. 292-305, August 2012.

[45] T. Munaga, M. M. Khan, and K. K. Gonavaram, "Axial and Lateral Loading Behaviour of Pervious Concrete Pile," Indian Geotechnical Journal, vol. 50, no. 3, pp. 505-513, June 2020.

[46] L. Ni, "Pervious Concrete Piles: Development and Investigation of an Innovative Ground Improvement System," Ph.D. dissertation, Department of Civil Engineering, Lehigh University, Bethlehem, PA, 2014.

[47] J. M. O. Hughes, N. J. Withers, and D. A. Greenwood, "A Field Trial of the Reinforcing Effect of a Stone Column in Soil," Geotechnique, vol. 25, no. 1, pp. 31-44, 1975.

[48] Design and Construction for Ground Improvement—Guidelines: Part 1 Stone Columns, IS: 15284 (Part 1), 2003.

[49] J. M. O. Hughes and N. J. Withers, "Reinforcing of Soft Cohesive Soils with Stone Columns," Ground Engineering, vol. 7, no. 3, pp. 42-49, 1974.

[50] M. R. Madhav and N. Miura, "Soil Improvement Panel Report on Stone Columns," 13th International Conference on Soil Mechanics and Foundation Engineering, pp. 163-164, January 1994.

Copyright $\odot$ by the authors. Licensee TAETI, Taiwan. This article is an open access article distributed under the terms and conditions of the Creative Commons Attribution (CC BY-NC) license (https://creativecommons.org/licenses/by-nc/4.0/). 